\title{
GAYA KOGNITIF FIELD DEPENDENT DAN TINGKAT PEMAHAMAN KONSEP MATEMATIS ANTARA PEMBELAJARAN LANGSUNG DAN STAD
}

\author{
Agung Putra Wijaya \\ Program Studi Pendidikan Matematika FKIP Universitas Lampung \\ e-mail: agung.wijaya@fkip.unila.ac.id.
}

\begin{abstract}
Abstrak
Penelitian korelasional ini bertujuan untuk mengetahui apakah terdapat korelasi positif antara gaya kognitif field dependent dan tingkat pemahaman konsep matematis pada siswa yang dikenai model pembelajaran langsung dan STAD. Populasi penelitian ini adalah seluruh siswa kelas VIII SMP Negeri di Lampung Selatan. Pengambilan sampel dilakukan dengan teknik cluster random sampling sehingga diperoleh dua kelas sampel penelitian. Metode tes diterapkan untuk mengumpulkan data. Instrumen penelitianini berupa GEFT dan tes pemahaman konsep matematis pada materi persamaan garis lurus. Berdasar pada hasil pengujian hipotesis, diperoleh simpulan bahwa (1) terdapat korelasi positif antara gaya kognitif field dependent dan tingkat pemahaman konsep matematis pada siswa yang dikenai model pembelajaran langsung dan (2) tidak terdapat korelasi positif antara gaya kognitif field dependent dan tingkat pemahaman konsep matematis pada siswa yang dikenai model pembelajaran STAD. Hasil ini berimplikasi bahwa model pembelajaran mempengaruhi tingkat pemahaman matematis siswa yang bergaya kognitif field dependent.
\end{abstract}

Kata kunci:field dependent, pemahaman konsep, pembelajaran langsung, STAD

This correlational research was aimed to find out whether there is a positive correlation between field dependent cognitive style and mathematical conceptual understanding of students who was taught by direct instructin and STAD model. The population of this research was all students of grade eighth of a Public Junior High School in Lampung Selatan. By cluster random sampling technique, there were two classes of research sample. The test method was applied to collect the data. The instruments of this research were GEFT and test of mathematical conceptual understanding of line equation material. Based on the result of hypotesis test, it was concluded that (1) there is a positive correlation between cognitive style and mathematical conceptual understanding on students who was taught by direct learning model and (2) there is no positive correlation between cognitive style and mathematical conceptual understanding on students who was taught by STAD learning model. This result implies that learning model affects mathematical conceptual understanding of student who has field dependent cognitive style.

Keywords:field dependent, conceptual understanding, direct instruction, STAD

\section{PENDAHULUAN}

Matematika merupakan salah satu mata pelajaran yang diajarkan pada setiap jenjang pendidikan. Hal ini mengindikasikan bahwa ilmu matematika merupakan ilmu penting yang erat kaitannya dengan kehidupan sehari-hari. Oleh karena itu, siswa dituntut agar memiliki pemahaman konsep matematis yang baik. Hal ini dimaksudkan agar kelak siswa dapat mengaplikasikan ilmu matematika tersebut dengan baik dalam kehidupan sehari-hari.

Hanya saja, kondisi di lapangan belum sesuai dengan kondisi yang diharapkan. Data Trends in International Mathematics and Science Study (TIMSS) tahun 2007 menunjukkan bahwa kemampuan matematika siswa Indonesia (rata-rata 397) 
Gaya Kognitif Field Dependent dan Tingkat Pemahaman Konsep Matematis Antara Pembelajaran Langsung dan STAD

Agung Putra Wijaya

menempati peringkat 36 dari 48 negara. kelas VIII SMP Negeri di Lampung

Berdasarkan pada data TIMSS tahun 2007 Selatan.

tersebut, skala matematika TIMSS-

Di antara banyak model pembelajaran,

Benchmark Internasional menempatkan terdapat model pembelajaran langsung dan kemampuan matematika siswa Indonesia pada skala rendah (peringkat bawah) (Shadiq, 2007: 1-2).

Hasil ujian nasional siswa SMP/MTs di Kabupaten Lampung Selatan pada Ujian Nasional tahun pelajaran 2011/2012 juga belum menunjukkan hasil yang memuaskan. Menurut Badan Standar Nasional Pendidikan, terdapat 2.631 dari 9.822 siswa peserta ujian nasional (sekitar 26,79\%) memperoleh nilai matematika di bawah rata-rata (sebesar 8,32 dengan simpangan baku sebesar 0,9). Berdasarkan hasil wawancara, guru matematika di kelas VIII SMP Negeri di Lampung Selatan membenarkan bahwa matematika masih menjadi momok bagi siswa. Observasi di kelas memberikan informasi bahwaguru matematika di kelas VIII SMP Negeri di Lampung Selatan masih menerapkan model pembelajaran konvensional, yaitu dengan menginformasikan algoritmadan rumus matematika kepada siswa, diberikanlatihan soal, dan diakhiri dengan memberikan tugas rumah. Hal ini membuat siswa cenderung pasif dan hanya menerima penjelasan dari guru. Mencermati kondisi tersebut, penerapan model pembelajaran yang tepat diduga dapat mengoptimalkan pemahaman konsep matematis siswa di model pembelajaran kooperatif yang dapat diterapkan di kelas. Model pembelajaran langsung merupakan suatu model pembelajaran yang menekankan pada penguasaan konsep dengan mengutamakan pendekatan deduktif. Menurut Sudrajat (2011), ciri-ciri model pembelajaran langsung adalah (1) pembelajaran berorientasi pada tujuan tertentu; (2) materi pembelajaran telah terstruktur; dan (3) guru berperan sebagai penyampai informasi. Informasi yang disampaikan dapat berupa pengetahuan prosedural atau deklaratif.Sementara itu, model pembelajaran kooperatif merupakan suatu model pembelajaran kelompok yang menghendaki adanya kerjasama antar anggota kelompok dalam memahamisuatu konsep. Salah satu tipe dari model pembelajaran kooperatif yang paling sederhana adalah model pembelajaran kooperatif tipe Student Teams Achievement Divisions (STAD). Menurut Isjoni (2010: 74), model pembelajaran kooperatif tipe STAD merupakan salah satu model pembelajaran kooperatif yang menekankan adanya aktivitas dan interaksi di antara siswa untuk saling memotivasi dan saling membantu dalam menguasai materi pembelajaran guna mencapai prestasi yang optimal. 
Selain model pembelajaran, gaya kognitif siswa juga menjadi faktor yang turut mempengaruhi pemahaman konsep matematis siswa. Menurut Slameto (2003: 160), gaya kognitif merupakan perbedaan antar individu yang menetap dalam cara menyusun dan mengolah informasi serta pengalaman-pengalaman. Pendapat senada diungkapkan oleh Uno (2006: 185) bahwa gaya kognitif merupakan cara siswa yang khas dalam belajar, baik yang berkaitan dengan cara penerimaan dan pengolahan informasi, sikap terhadap informasi maupun kebiasaan yang berhubungan dengan lingkungan belajar.

Hasil observasi pada siswa kelas VIII SMP Negeri di Lampung Selatan menunjukkan bahwa sebagian besar siswa menganggap matematika sebagai mata pelajaran yang sulit. Siswa cenderung lebih tertarik dengan mata pelajaran sosial dibandingkan mata pelajaran matematika. Untuk dapat memahami konsep matematis dengan baik sehingga mampu memecahkan masalah, siswa memerlukan penjelasan secara detail dan contoh-contoh soal. Mencermati karakteristik tersebut, siswa kelas VIII SMP Negeri di Lampung Selatan cenderung memiliki gaya kognitif field dependent.

Mencermati pendapat ahli di atas, gaya kognitif siswa diduga mempengaruhi tingkat pemahaman konsep matematis siswa. Pada suatu model pembelajaran tertentu, siswa yang memiliki gaya kognitif tertentu diduga memiliki tingkat pemahaman yang berbeda dengan siswa yang memiliki gaya kognitif lain terhadap konsep yang sama. Dengan demikian, perlu dilakukan penelitian dengan tujuan untuk mengetahui apakah terdapat korelasi positif antara gaya kognitif field dependent dan pemahaman konsep matematis siswa kelas VIII SMP di Lampung Selatan pada kelas yang dikenai model pembelajaran langsung dan STAD.

\section{TINJAUAN PUSTAKA}

\section{A. Model Pembelajaran Langsung}

Model pembelajaran langsung merupakan suatu model pembelajaran yang menekankan pada penguasaan konsep dengan mengutamakan pendekatan deduktif. Menurut Sudrajat (2011), ciri-ciri model pembelajaran langsung adalah (1) pembelajaran berorientasi pada tujuan tertentu; (2) materi pembelajaran telah terstruktur; (3) lingkungan belajar telah terstruktur; dan (4) guru berperan sebagai penyampai informasi. Informasi yang disampaikan dapat berupa pengetahuan prosedural (pengetahuan tentang bagaimana melaksanakan sesuatu) atau pengetahuan deklaratif (pengetahuan tentang sesuatu dapat berupa fakta, konsep, prinsip, atau generalisasi). Dengan kata lain, model pembelajaran langsung merupakan suatu model pembelajaran yang dapat membantu siswa dalam memahami suatu konsep atau menguasai suatu 
Gaya Kognitif Field Dependent dan Tingkat Pemahaman Konsep Matematis Antara Pembelajaran Langsung dan STAD

Agung Putra Wijaya

keterampilan dasar dan memperoleh suatu

adanya aktivitas dan interaksi di antara

informasi yang diajarkan selangkah demi siswa untuk saling memotivasi dan saling selangkah (step by step).

Penerapan model pembelajaran langsung memiliki lima fase yang sangat penting. Kelima fase tersebut adalah fase orientasi, presentasi atau demonstrasi, latihan terstruktur, latihan terbimbing, dan latihan mandiri. Kelima fase tersebut membutuhkan bimbingan dari seorang guru. Menurut Setiawan (2010: 8), lima fase dalam penerapan model pembelajaran langsung, yakni (1) menyampaikan tujuan dan mempersiapkan siswa, (2) presentasi dan demonstrasi, (3) membimbing pelatihan, (4) mengecek pemahaman dan memberikan umpan balik, dan (5) memberikan kesempatan untuk pelatihan lanjutan dan penerapan.

\section{B. Model Pembelajaran STAD}

Model pembelajaran STAD dipandang sebagai model pembelajaran kooperatif yang paling sederhana dan mudah untuk diterapkan di kelas. Model pembelajaran ini banyak direkomendasikan bagi guru yang belum terbiasa dalam menerapkan model pembelajaran kooperatif di kelas. Model pembelajaran ini menuntut siswa untuk memiliki kemampuan berkomunikasi dan keterampilan proses berkelompok yang memadai. Menurut Isjoni (2010: 74), model pembelajaran STAD merupakan salah satu model pembelajaran kooperatif yang menekankan membantu dalam menguasai materi pembelajaran guna mencapai prestasi yang optimal.

Layaknya model pembelajaran lain, model pembelajaran $S T A D$ juga memiliki langkah-langkah khusus dalam penerapannya. Slavin (2010: 143) menyebutkan langkah-langkahdalam penerapan model pembelajaran $S T A D$ adalah (1) presentasi kelas; materi pelajaran disampaikan melalui presentasi kelas oleh guru. presentasi kelas ini tidak berbeda dengan pembelajaran biasa, hanya berbeda pada pemfokusan terhadap model pembelajaran $S T A D$, (2) tim atau kelompok; kelompok terdiri dari 4 sampai 5 siswa dengan memperhatikan perbedaan kemampuan akademik, jenis kelamin, dan ras atau etnisnya. kerja sama kelompok merupakan ciri penting dalam model pembelajaran STAD karena setiap anggota kelompok harus bertanggungjawab atas keberhasilan anggota kelompok lain, (3) kuis atau tes; setelah melaksanakan 1 atau 2 kali diskusi kelompok, siswa diberikan tes yang harus diselesaikan secara individual. guru harus mengkondisikan kelas sedemikian sehingga tidak ada siswa yang bekerja sama dalam mengerjakan soal kuis, (4) poin peningkatan individual; ide yang mendasari poin peningkatan individual adalah keinginan untuk menunjukkan kepada siswa sasaran yang dapat dicapai jika 
belajar lebih giat dan memperlihatkan peningkatan prestasi belajar dibandingkan prestasibelajar yang telah dicapai sebelumnya, dan (5) penghargaan kelompok; setelah poin peningkatan individual dihitung, dilanjutkan denganpenentuan penghargaan kelompok. penghargaan kelompok diberikan berdasarkan poin peningkatan individu.

\section{Gaya Kognitif Field Dependent}

Setiap siswa memiliki perbedaan dalam cara memperoleh, menyimpan, dan menerapkan sejumlah pengetahuan. Setiap siswa memiliki cara yang berbeda-beda dalam memproses pemahamannya berkenaan dengan apa yang dilihat, diingat, dan dipikirkannya. Menurut Slameto (2003: 160), perbedaan antar individu yang menetap dalam cara menyusun dan mengolah informasi serta pengalamanpengalaman ini dikenal dengan gaya kognitif. Pendapat senada juga diungkapkan oleh Uno (2006: 185) yang menyatakan bahwa gaya kognitif merupakan cara siswa yang khas dalam belajar, baik yang berkaitan dengan cara penerimaan dan pengolahan informasi, sikap terhadap informasi maupun kebiasaan yang berhubungan dengan lingkungan belajar.

Perbedaan karakteristik gaya kognitif siswa merupakan suatu perbedaan karakteristik dari dalam diri siswa dalam memproses sejumlah informasi yang diterimanya. Gaya kognitif dapat dipandang sebagai suatu variabel dalam pembelajaran. Dalam hal ini, gaya kognitif merupakan variabel karakteristik siswa dan bersifat internal. Artinya, gaya kognitif merupakan kapabilitas siswa yang berkembang seiring dengan perkembangan kecerdasaanya. Menurut Uno (2006: 191), gaya kognitif bersifat given dan dapat berpengaruh pada prestasi belajar. Dalam hal ini, siswa yang memiliki gaya kognitif tertentu memerlukan strategi pembelajaran tertentu pula untuk memperoleh prestasi belajar yang baik.

Terdapat banyak penggolongan gaya kognitif. Menurut Nasution (2008: 94), ditinjau dari adanya pengaruh lingkungan dan riwayat pendidikan masa lalu, gaya kogitif digolongkan menjadi filed independent dan filed dependent. Terdapat perbedaan yang sangat kontras antara gaya kognitif filed independent dan filed dependent. Menurut Desmita, 2009: 149, karakter pembelajaran pada diri siswa yang memiliki gaya kognitif field independent adalah (1) mungkin perlu bantuan memfokuskan perhatian pada materi dengan muatan sosial, (2) mungkin perlu diajarkan bagaimana konteks untuk memahami informasi sosial, (3) cenderung memiliki tujuan diri yang terdefinisikan dan penguatan, (4) tidak terpengaruh kritik, (5) dapat mengembangkan strukturnya sendiri pada situasi tak terstruktur, dan (6) Biasanya lebih mampu memecahkan masalah tanpa instruksi dan bimbingan 
Gaya Kognitif Field Dependent dan Tingkat Pemahaman Konsep Matematis Antara Pembelajaran Langsung dan STAD

Agung Putra Wijaya

eksplisit. Berbeda dengan gaya kognitif yang baik untuk mencapai kemampuan

field independent, karakter pembelajaran dasar yang lain seperti penalaran, komupada diri siswa yang memiliki gaya nikasi, koneksi dan pemecahan masalah. kognitif field dependent adalah (1) lebih mudah untuk memahami materi pembelajaran dengan mengandung muatan sosial, (2) memiliki ingatan lebih baik untuk masalah sosial, (3) memiliki struktur, tujuan, dan penguatan yang didefinisikan secara jelas, (4) lebih terpengaruh kritik, (5) memiliki kesulitan besar untuk mempelajari materi terstruktur, (6) mungkin perlu diajarkan bagaimana menggunakan mnemonic, (7) cenderung menerima organisasi yang diberikan dan tidak mampu untuk mengorganisasi kembali, dan (8) mungkin memerlukan instruksi yang lebih jelas mengenai bagaimana memecahkan masalah. Mencermati karakteristik tersebut, siswa yang memiliki gaya kognitif field dependent cenderung lebih tertarik dengan kelompok ilmu-ilmu sosial dibandingkan matematika. Dengan demikian, gaya kognitif field dependent menarik untuk diteliti korelasinya dengan tingkat pemahaman konsep matematis siswa.

\section{Pemahaman Konsep Matematis}

Pemahaman konsep sangat penting, karena dengan pemahaman akan memudahkan siswa dalam mempelajari matematika. Pada setiap pembelajaran diusahakan lebih ditekankan pada pemahaman konsep agar siswa memiliki bekal dasar Menurut Purwanto (1994:44), pemahaman adalah tingkat kemampuan yang mengharapkan siswa mampu memahami arti atau konsep, situasi serta fakta yang diketahuinya. Sementara Mulyasa (2003: 78) menyatakan bahwa pemahaman adalah kedalaman kognitif dan afektif yang dimiliki oleh individu. Selanjutnya Ernawati (2003:8) mengemukakan bahwa pemahaman adalah kemampuan menangkap pengertian-pengertian seperti mampu mengungkapkan suatu materi yang disajikan dalam bentuk lain yang dapat dipahami, mampu memberikan interpretasi dan mampu mengklasifikasikannya. Virlianti (2002:6) mengemukakan bahwa pemahaman adalah konsepsi yang bisa dicerna atau dipahami oleh siswa sehingga mengerti apa yang dimaksudkan, mampu menemukan cara untuk mengungkapkan konsepsi tersebut, serta dapat mengeksplorasi kemungkinan yang terkait. Setiap materi pembelajaran matematika berisi sejumlah konsep yang harus dipahami siswa. Menurut Ruseffendi (2006:157), konsep adalah suatu ide abstrak yang memungkinkan untuk mengklasifikasikan atau mengelompokkan objek atau kejadian itu merupakan contoh dan bukan contoh dari ide tersebut.

Pemahaman konsep merupakan tingkatan hasil belajar siswa sehingga dapat 
mendefinisikan atau menjelaskan sebagian atau mendefinisikan bahan pelajaran dengan menggunakan kalimat sendiri. Dengan kemampuan menjelaskan atau mendefinisikan, siswa telah memahami konsep atau prinsip dari suatu pelajaran meskipun penjelasan yang diberikan mempunyai susunan kalimat yang tidak sama tetapi memiliki makna yang sama.

Menurut Sanjaya (2009), pemahaman konsep adalah kemampuan siswa yang berupa penguasaan sejumlah materi pelajaran, dimana siswa tidak sekedar mengetahui atau mengingat sejumlah konsep yang dipelajari, tetapi mampu mengungkapan kembali dalam bentuk lain yang mudah dimengerti, memberikan interprestasi data dan mampu mengaplikasikan konsep yang sesuai dengan struktur kognitif yang dimilikinya. Dengan kata lain, pemahaman konsep adalah kemampuan yang dimiliki seseorang untuk mengemukakan kembali ilmu yang diperolehnya baik dalam bentuk ucapan maupun tulisan kepada orang sehingga orang lain tersebut benar-benar mengerti apa yang disampaikan.

\section{METODE PENELITIAN}

Populasi penelitian ini adalah seluruh siswa kelas VIII SMP Negeri di Lampung Selatan. Dengan teknik cluster random sampling, diperoleh siswa kelas VIII F dan VII G sebagai sampel penelitian. Kelas VIII G dengan siswa sebanyak 33 orang bertindak sebagai kelas yang dikenai model pembelajaran langsung. Kelas VIII F dengan siswa sebanyak 39 orang bertindak sebagai kelas yang dikenai model pembelajaran kooperatif tipe STAD.

Dalam penelitian ini, model pembelajaran langsung yang diterapkan berpusat pada guru dengan langkahlangkah pembelajaran, yakni (1) guru menyampaikan tujuan pembelajaran dan menyiapkan siswa untuk belajar, (2) guru menjelaskan materi pelajaran dengan metode ceramah, (3) guru memberikan latihan soal dan membimbing siswa dalam mengerjakan latihan soal, (4) guru mengecek pemahaman dan memberikan umpan balik, dan (5) guru memberikan soal untuk dikerjakan siswa di rumah. Berbeda dengan model pembelajaran langsung, model pembelajaan kooperatif tipe $S T A D$ diterapkan dengan langkah-langkah (1) guru menyampaikan tujuan pembelajaran, (2) guru menyajikan materi pelajaran secara garis besar, (3) guru mengkondisikan siswa dalam kelompok belajar yang terdiri dari 4 sampai 5 siswa dengan memperhatikan perbedaan kemampuan akademik dan jenis kelamin dan membagikan lembar kerja kepada setiap kelompok, (4) siswa melakukan diskusi kelompok untuk menyelesaikan masalah pada lembar kerja, (5) siswa melakukan diskusi kelas, (6) dengan bimbingan guru, siswa menyimpulkan materi pelajaran, dan (7) guru memberikan soal untuk dikerjakan siswa di rumah. 
Gaya Kognitif Field Dependent dan Tingkat Pemahaman Konsep Matematis Antara Pembelajaran Langsung dan STAD

Agung Putra Wijaya

Penelitian ini adalah penelitian siswa. Instrumen tes pemahaman konsep

eksperimental semu (quasi experimental matematis yang disusun oleh peneliti research). Setelah melakukan sampling, berupa soal uraian. Sebelum instrumen tes peneliti melakukan pembelajaran pada ini digunakan, terlebih dahulu kelas yang telah ditentukan. Penelitian ini dikonsultasikan kepada guru matematika dilakukan pada materi persamaan garis kelas VIII SMP. Guru matematika kelas lurus kelas VIII. Dalam penelitian ini, metode pengumpulan data yang digunakan meliputi metode tes. Tes diberikan setelah pembelajaran selesai dilakukan. Metode tes ini digunakan untuk memperoleh data gaya VIII SMP menyatakan bahwa instrumen tes ini valid ditinjau dari validitas isi dan layak untuk diujikan pada siswa kelas VIII. Pedoman penskoran tes pemahaman konsep matematis disajikan pada Tabel 1.

kognitif dan pemahaman konsep matematis

Tabel 1. Pedoman Penskoran Tes Pemahaman Konsep Matematis

\begin{tabular}{|c|c|c|c|}
\hline No & Indikator & Keterangan & Skor \\
\hline \multirow[t]{5}{*}{1.} & \multirow[t]{5}{*}{$\begin{array}{l}\text { Menyatakan } \\
\text { ulang konsep }\end{array}$} & $\begin{array}{l}\text { Tidak ada jawaban atau tidak ada ide matematika } \\
\text { yang muncul sesuai dengan soal. }\end{array}$ & 0 \\
\hline & & $\begin{array}{l}\text { Ide matematik telah muncul namun belum dapat } \\
\text { menyatakan ulang konsep dengan tepat dan } \\
\text { masih banyak melakukan kesalahan. }\end{array}$ & 1 \\
\hline & & $\begin{array}{l}\text { Telah dapat menyatakan ulang sebuah konsep } \\
\text { namun belum dapat dikembangkan dan masih } \\
\text { melakukan banyak kesalahan. }\end{array}$ & 2 \\
\hline & & $\begin{array}{l}\text { Dapat menyatakan ulang sebuah konsep sesuai } \\
\text { dengan definisi dan konsep esensial yang dimiliki } \\
\text { oleh sebuah objek namun masih melakukan beberapa } \\
\text { kesalahan. }\end{array}$ & 3 \\
\hline & & $\begin{array}{l}\text { Dapat menyatakan ulang sebuah konsep sesuai } \\
\text { dengan definisi dan konsep esensial yang dimiliki } \\
\text { oleh sebuah objek dengan tepat. }\end{array}$ & 4 \\
\hline \multirow[t]{5}{*}{2.} & \multirow{5}{*}{$\begin{array}{l}\text { Mengklasifikasi } \\
\text { objek menurut } \\
\text { sifat tertentu } \\
\text { sesuai } \\
\text { dengan } \\
\text { konsepnya }\end{array}$} & $\begin{array}{l}\text { Tidak ada jawaban atau Tidak ada ide } \\
\text { matematika yang muncul sesuai dengan soal. }\end{array}$ & 0 \\
\hline & & $\begin{array}{l}\text { Ide matematik telah muncul namun belum dapat } \\
\text { menganalisis suatu objek dan mengklasifikasikannya } \\
\text { menurut sifat-sifat/ciri-ciri tertentu yang dimiliki } \\
\text { sesuai dengan konsepnya. }\end{array}$ & 1 \\
\hline & & $\begin{array}{l}\text { Telah dapat menganalisis suatu objek namun belum } \\
\text { dapat mengklasifikasikannya menurut sifat-sifat/ciri- } \\
\text { ciri dan konsepnya yang dimiliki. }\end{array}$ & 2 \\
\hline & & $\begin{array}{l}\text { Dapat menganalisis suatu objek dan } \\
\text { mengklasifikasikannya menurut sifat-sifat/ciri-ciri dan } \\
\text { konsepnya tertentu yang dimiliki namun masih } \\
\text { melakukan beberapa kesalahan operasi matematis. }\end{array}$ & 3 \\
\hline & & $\begin{array}{l}\text { Dapat menganalisis suatu objek dan mengklasifikasi- } \\
\text { kannya menurut sifat-sifat/ciri-ciri dan }\end{array}$ & 4 \\
\hline
\end{tabular}




\begin{tabular}{|c|c|c|c|}
\hline No & Indikator & Keterangan & Skor \\
\hline & & konsepnya tertentu yang dimiliki dengan tepat. & \\
\hline \multirow[t]{5}{*}{3.} & \multirow{5}{*}{$\begin{array}{l}\text { Memberi } \\
\text { contoh } \\
\text { dan non contoh }\end{array}$} & $\begin{array}{l}\text { Tidak ada jawaban atau tidak ada ide matematika } \\
\text { yang muncul sesuai dengan soal. }\end{array}$ & 0 \\
\hline & & $\begin{array}{l}\text { Ide matematik telah muncul namun belum dapat } \\
\text { menyebutkan konsep yang dimiliki oleh setiap } \\
\text { contoh yang diberikan. }\end{array}$ & 1 \\
\hline & & $\begin{array}{l}\text { Telah dapat memberikan contoh dan noncontoh } \\
\text { sesuai dengan konsep yang dimiliki objek namun } \\
\text { belum tepat dan belum dapat dikembangkan. }\end{array}$ & 2 \\
\hline & & $\begin{array}{l}\text { Telah dapat memberikan contoh dan non contoh } \\
\text { sesuai dengan konsep yang dimiliki objek namun } \\
\text { pengembangannya belum tepat. }\end{array}$ & 3 \\
\hline & & $\begin{array}{l}\text { Telah dapat memberikan contoh dan noncontoh } \\
\text { sesuai dengan konsep yang dimiliki objek dan } \\
\text { telah dapat dikembangkan. }\end{array}$ & 4 \\
\hline \multirow[t]{5}{*}{4.} & \multirow{5}{*}{$\begin{array}{l}\text { Menyatakan } \\
\text { konsep dalam } \\
\text { berbagai bentuk } \\
\text { representasi } \\
\text { matematika }\end{array}$} & $\begin{array}{l}\text { Tidak ada jawaban atau tidak ada ide matematika } \\
\text { yang muncul sesuai dengan soal. }\end{array}$ & 0 \\
\hline & & $\begin{array}{l}\text { Ide matematik telah muncul namun belum dapat } \\
\text { menyajikan konsep dalam berbagai bentuk } \\
\text { representasi matematis. }\end{array}$ & 1 \\
\hline & & $\begin{array}{l}\text { Dapat menyajikan konsep dalam berbagai bentuk } \\
\text { representasi matematis namun belum memahami } \\
\text { logaritma pemahaman konsep. }\end{array}$ & 2 \\
\hline & & $\begin{array}{l}\text { Dapat menyajikan konsep dalam berbagai bentuk } \\
\text { representasi matematis sebagai suatu logaritma } \\
\text { pemahaman konsep namun masih melakukan } \\
\text { beberapa kesalahan. }\end{array}$ & 3 \\
\hline & & $\begin{array}{l}\text { Dapat menyajikan konsep dalam bentuk repre- } \\
\text { sentasi matematika dengan benar. }\end{array}$ & 4 \\
\hline \multirow[t]{5}{*}{5.} & \multirow{5}{*}{$\begin{array}{l}\text { Menggunakan, } \\
\text { memanfaatkan, } \\
\text { dan } \\
\text { memilih } \\
\text { prosedur } \\
\text { atau operasi } \\
\text { tertentu }\end{array}$} & $\begin{array}{l}\text { Tidak ada jawaban atau tidak ada ide matematika } \\
\text { yang muncul sesuai dengan soal. }\end{array}$ & 0 \\
\hline & & $\begin{array}{l}\text { Ide matematik telah muncul namun belum dapat } \\
\text { menyajikan konsep dalam berbagai bentuk } \\
\text { representasi matematis. }\end{array}$ & 1 \\
\hline & & $\begin{array}{l}\text { Dapat menyajikan konsep dalam berbagai bentuk } \\
\text { representasi matematis namun belum memahami } \\
\text { logaritma pemahaman konsep. }\end{array}$ & 2 \\
\hline & & $\begin{array}{l}\text { Dapat menyajikan konsep dalam berbagai bentuk } \\
\text { representasi matematis sebagai suatu logaritma } \\
\text { pemahaman konsep namun masih melakukan } \\
\text { beberapa kesalahan. }\end{array}$ & 3 \\
\hline & & $\begin{array}{l}\text { Mampu menggunakan, memanfaatkan, dan } \\
\text { memilih prosedur dengan benar. }\end{array}$ & 4 \\
\hline \multirow[t]{3}{*}{6.} & \multirow[t]{3}{*}{$\begin{array}{l}\text { Mengaplikasi- } \\
\text { kan konsep }\end{array}$} & $\begin{array}{l}\text { Tidak ada jawaban atau tidak ada ide } \\
\text { matematika yang muncul sesuai dengan soal. }\end{array}$ & 0 \\
\hline & & $\begin{array}{l}\text { Ide matematik telah muncul namun belum dapat } \\
\text { menyajikan konsep dalam berbagai bentuk } \\
\text { representasi matematis sebagai suatu logaritma } \\
\text { pemahaman konsep. }\end{array}$ & 1 \\
\hline & & Dapat menyajikan konsep dalam berbagai bentuk & 2 \\
\hline
\end{tabular}


Gaya Kognitif Field Dependent dan Tingkat Pemahaman Konsep Matematis Antara Pembelajaran Langsung dan STAD

Agung Putra Wijaya

\begin{tabular}{|c|c|l|c|}
\hline No & Indikator & \multicolumn{1}{|c|}{ Keterangan } & Skor \\
\hline & & $\begin{array}{l}\text { representasi matematis namun belum memahami } \\
\text { logaritma pemahaman konsep. }\end{array}$ & \\
\cline { 3 - 4 } & $\begin{array}{l}\text { Dapat menyajikan konsep dalam berbagai bentuk } \\
\text { representasi matematis sebagai suatu logaritma } \\
\text { pemahaman konsep namun masih melakukan } \\
\text { beberapa kesalahan. }\end{array}$ & 3 \\
\cline { 2 - 3 } & $\begin{array}{l}\text { Dapat menyajikan konsep dalam berbagai bentuk } \\
\text { representasi matematis sebagai suatu logaritma } \\
\text { pemahaman konsep dengan tepat. }\end{array}$ & 4 \\
\hline
\end{tabular}

Gaya kognitif siswa diukur field dependent dan siswa yang memmenggunakan instrumen standar untuk tes gaya kognitif, yakni Group Embeded Figures Test (GEFT). Instrumen ini pertama kali disusun oleh Witkin pada 1971 dengan koefesien reliabilitas sebesar 0,82 dan telah banyak digunakan oleh peneliti lain di Indonesia, seperti Saputro (2011) dan Moertiningsih (2011). GEFT terdiri dari 25 gambar kompleks yang dibagi ke dalam tiga tahap dengan waktu pengerjaan maksimal 15 menit. Tahap pertama merupakan tahap practice atau latihan, sedangkan tahap kedua dan ketiga merupakan tahap ujian dan penilaian yang masing-masing terdiri dari 9 gambar kompleks. GEFT ini terdiri dari 18 butir soal dengan ketentuan penilaiannya, yakni untuk setiap nomor yang dijawab benar diberi skor 1 dan yang dijawab salah diberi skor 0. Dengan demikian, rentang nilai GEFT adalah antara 0 sampai 18. Penggolongan kategori gaya kognitif siswa mengacu pada pendapat Kepner dan Neimark (1984: 1408) yang menyatakan bahwa siswa yang memperoleh skor 0 sampai 9 digolongkan dalam gaya kognitif peroleh skor 10 sampai 18 digolongkan dalam gaya kognitif field independent.

Data penelitian ini berupa data skor gaya kognitif dan pemahaman konsep matematis siswa. Untuk pengujian hipotesis, data dianalisis menggunakan uji korelasi. Sebelumnya, terhadap data tersebut dilakukan uji prasyarat, yakni uji normalitas populasi. Uji normalitas populasi ini dilakukan untuk mengetahui apakah sampel penelitian ini berasal dari populasi yang berdistribusi normal atau tidak. Dalam penelitian ini, uji normalitas populasi menggunakan metode Lilliefors (Budiyono (2009: 170-171)).

Statistik uji yang digunakan adalah $t_{\text {hitung }}$ (Budiyono (2009: 273)). Hipotesis uji korelasi antara gaya kognitif dan pemahaman konsep matematis siswa, baik pada kelas yang dikenai model pembelajaran langsung maupun STAD sebagai berikut.

$\mathrm{H}_{0}: \rho \leq 0$ (tidak terdapat korelasi positif antara gaya kognitif dan tingkat pemahaman konsep matematis siswa) 
$\mathrm{H}_{1}: \rho>0$ (terdapat korelasi positif antara gaya kognitif dan tingkat pemahaman konsep matematis siswa).

\section{HASIL DAN PEMBAHASAN}

Data penelitian ini berupa data gaya kognitif dan pemahaman konsep matematis siswa, baik pada kelas yang dikenai model pembelajaran langsung maupun model pembelajaran STAD. Untuk lebih jelasnya, data gaya kognitif dan pemahaman konsep matematisdisajikan secara berdampingan bersesuaian dengan masing-masing siswa.

Data gaya kognitif dan pemahaman konsep matematis siswa pada kelas yang dikenai model pembelajaran langsung disajikan pada Diagram 1.

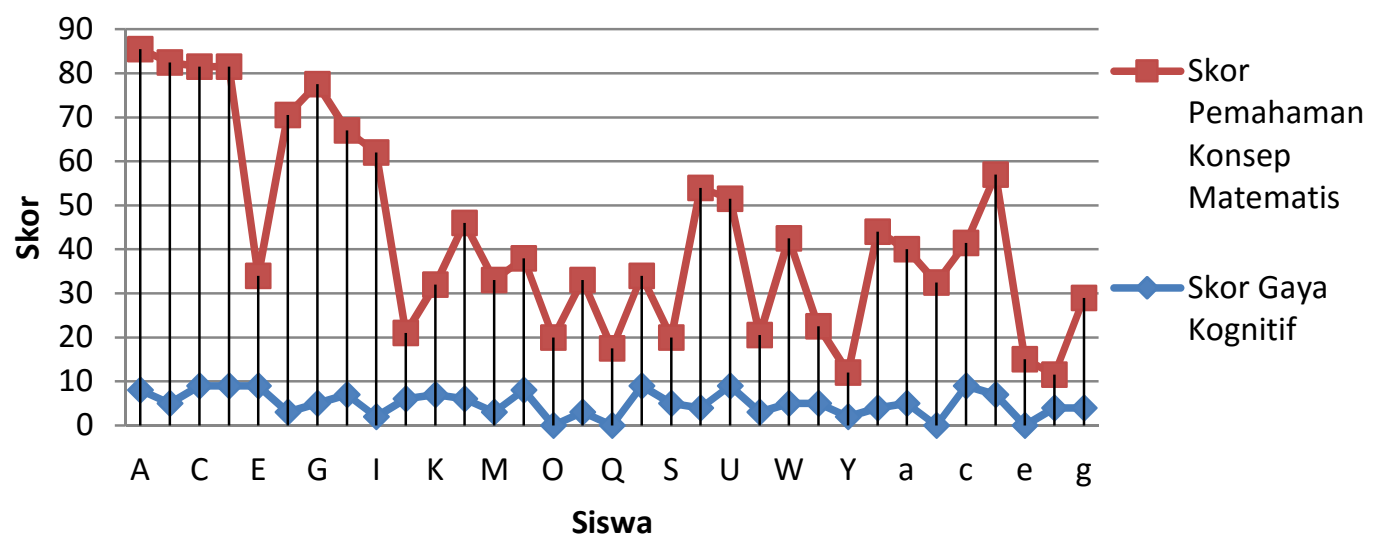

\section{Diagram1. Data Gaya Kognitif dan Pemahaman Konsep Matematis Siswa pada Kelas yang Dikenai Model Pembelajaran Langsung}

Selain data pada kelas yang dikenai model pembelajaran langsung, hasil penelitian ini juga berupa data gaya kognitif dan pemahaman konsep matematis siswa yang dikenai model pembelajaran
STAD. Data skor gaya kognitif dan pemahaman konsep matematis siswa pada kelas yang dikenai model pembelajaran STAD disajikan pada Diagram 2. 


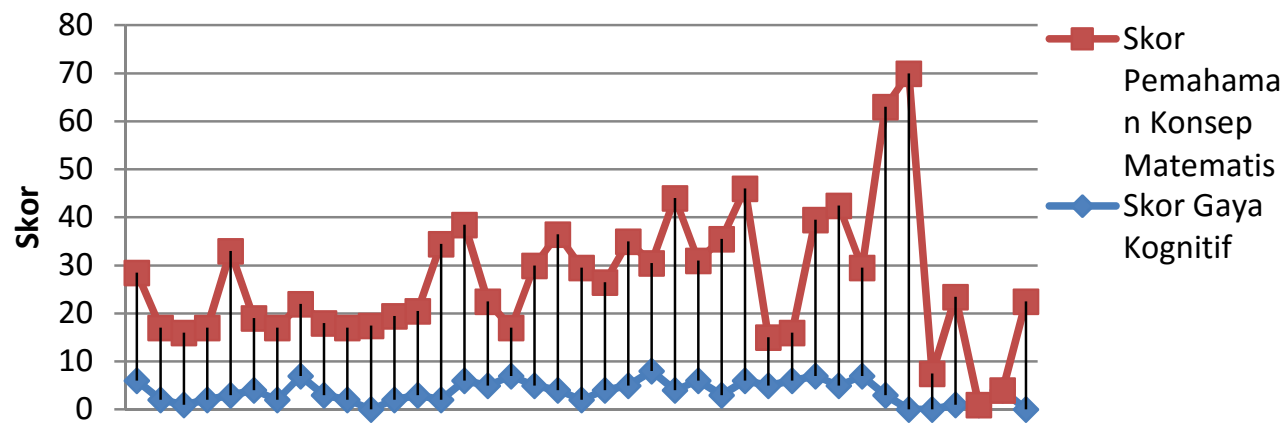

A C E G I K M O Q S U

Siswa

\section{Diagram 2. Data Gaya Kognitif dan Pemahaman Konsep Matematis Siswa pada Kelas yang Dikenai Model Pembelajaran STAD}

Sebelum dilakukan pengujian hipotesis, terhadap data penelitian dilakukan pengujian prasyarat. Uji prasyarat untuk pengujian hipotesis menggunakan uji korelasi adalah uji normalitas populasi.
Dengan taraf signifikansi 0,05, rangkuman hasil uji normalitas populasi menggunakan metode Lilliefors terhadap data pemahaman konsep matematis siswa disajikan dalam Tabel 2.

Tabel 2. Rangkuman Hasil Uji Normalitas Populasi

\begin{tabular}{|c|c|c|c|c|c|c|}
\hline Variabel & Kelas & $\boldsymbol{N}$ & $\boldsymbol{L}_{\text {hit }}$ & $\boldsymbol{L}_{\mathbf{0 , 0 5} ; \boldsymbol{n}}$ & Keputusan Uji & Kesimpulan \\
\hline Gaya & Langsung & 33 & 0,1061 & 0,1542 & $\mathrm{H}_{0}$ tidak ditolak & Normal \\
\cline { 2 - 7 } Kognitif & STAD & 39 & 0,1271 & 0,1419 & $\mathrm{H}_{0}$ tidak ditolak & Normal \\
\hline Pemahaman & Langsung & 33 & 0,1419 & 0,1542 & $\mathrm{H}_{0}$ tidak ditolak & Normal \\
\cline { 2 - 7 } Konsep & STAD & 39 & 0,1392 & 0,1419 & $\mathrm{H}_{0}$ tidak ditolak & Normal \\
\hline
\end{tabular}

Berdasarkan hasil uji normalitas populasi, setiap sampel mempunyai nilai $L_{h i k}$ kurang dari nilai $L_{0,05 ; n}$. Hal ini berarti pada taraf signifikansi 0,05 , keputusan uji normalitas populasi untuk setiap sampel adalah $\mathrm{H}_{0}$ tidak ditolak. Dengan demikian, diperoleh simpulan bahwa semua sampel pada penelitian ini berasal dari populasi yang berdistribusi normal.

Oleh karena hasil pengujian prasyarat menyimpulkan bahwa data penelitian pada kedua kelas berdistribusi normal, maka pengujian hipotesis penelitian dapat dilanjutkan menggunakan uji korelasi. Uji korelasi ini dilakukan untuk melihat apakah terdapat hubungan antara gaya kognitif dan pemahaman konsep matematis siswa, baik pada kelas yang dikenai model pembelajaran langsung dan STAD. Uji korelasi antara gaya kognitif dan pemahaman konsep matematis siswa dilakukan pada masing-masing kelas. Dengan taraf signifikansi 0,05, rangkuman hasil perhitungan uji korelasi disajikan dalam Tabel 3. 
Tabel 3. Rangkuman Hasil Uji Korelasi

\begin{tabular}{|c|c|c|c|l|l|}
\hline Kelas & $\boldsymbol{n}$ & $\boldsymbol{t}_{\text {hit }}$ & $\boldsymbol{t}_{(\mathbf{0}, \mathbf{0} ; \mathbf{n}-\mathbf{2})}$ & \multicolumn{1}{|c|}{ Keputusan Uji } & \multicolumn{1}{|c|}{ Kesimpulan } \\
\hline Langsung & 33 & 2,0416 & 1,6450 & $\mathrm{H}_{0}$ ditolak & $\begin{array}{l}\text { Terdapat } \\
\text { korelasi positif }\end{array}$ \\
\hline STAD & 39 & 0,0042 & 1,6450 & $\mathrm{H}_{0}$ tidak ditolak & $\begin{array}{l}\text { Tidak terdapat } \\
\text { korelasi positif }\end{array}$ \\
\hline
\end{tabular}

Berdasarkan hasil pengujian korelasi antara gaya kognitif dan pemahaman konsep matematis pada siswa yang dikenai model pembelajaran langsung, diperoleh nilai $t_{h i t}$ sebesar 2,0416 dan $t_{(0,05 ; 31)}$ sebesar 1,6450 dengan $\mathrm{DK}=\{\mathrm{t} \mid \mathrm{t}>1,6450\}$ sehingga $t_{h i t}$ terletak pada daerah kritik. Hal ini berarti bahwa pada taraf signifikansi 0,05 , keputusan pengujian korelasi antara gaya kognitif dan pemahaman konsep matematis siswa pada kelas yang dikenai model pembelajaran langsung adalah $\mathrm{H}_{0}$ ditolak. Dengan demikian, hasil pengujian menunjukkan bahwa pada kelas yang dikenai model pembelajaran langsung, terdapat korelasi positif antara gaya kognitif dan pemahaman konsep matematis siswa.

Hasil pengujian korelasi antara gaya kognitif dan pemahaman konsep matematis pada siswa yang dikenai model pembelajaran kooperatif tipe STAD memberikan nilai $t_{h i t}$ sebesar 0,0042 dan $t_{(0,05 ; 37)}$ Sebesar $\quad 1,6450 \quad$ dengan $\mathrm{DK}=\{\mathrm{t} \mid \mathrm{t}>1,6450\}$ sehingga $t_{\text {hit }} \mathrm{tidak}$ terletak pada daerah kritik. Hal ini berarti bahwa pada taraf signifikansi 0,05, keputusan pengujian korelasi antara gaya kognitif dan pemahaman konsep matematis pada siswa yang dikenai model pembelajaran kooperatif tipe $S T A D$ adalah $\mathrm{H}_{0}$ tidak ditolak. Dengan demikian, pada kelas yang dikenai model pembelajaran kooperatif tipe STAD, tidak terdapat korelasi positif antara gaya kognitif dan pemahaman konsep matematis siswa.

Hasil uji korelasi menyimpulkan bahwa pada kelas yang dikenai model pembelajaran langsung, terdapat korelasi positif antara gaya kognitif dengan pemahaman konsep matematis siswa. Hal ini menunjukkan bahwa pemahaman konsep matematis siswa yang dikenai model pembelajaran langsung berbanding lurus terhadap gaya kognitifnya. Dengan kata lain, pada model pembelajaran langsung, semakin kecil gaya kognitif seorang siswa, semakin rendah pemahaman konsep matematis siswa. Sebaliknya, semakin besar gaya kognitif seorang siswa, semakin tinggi pula pemahaman konsep matematis siswa.

Hasil analisis terhadap gaya kognitif siswa, baik pada kelas yang dikenai model pembelajaran langsung maupun STAD, menunjukkan seluruh sampel memiliki gaya kognitif field dependent. Semakin 
Gaya Kognitif Field Dependent dan Tingkat Pemahaman Konsep Matematis Antara Pembelajaran Langsung dan STAD

Agung Putra Wijaya

rendah skor gaya kognitif field dependent siswa, semakin kuat gaya kognitif field dependent siswa tersebut. Sebaliknya, semakin tinggi skor gaya kognitif field dependent siswa, semakin lemah gaya kognitif field dependent siswa tersebut.

Pada model pembelajaran langsung, kuat atau lemahnya gaya kognitif field dependent seorang siswa berpengaruh terhadap pemahaman konsep matematis siswa. Semakin kuat gaya kognitif field dependent seorang siswa, semakin rendah pemahaman konsep matematis yang diperolehnya. Sebaliknya, semakin lemah gaya kognitif field dependent seorang siswa, semakin tinggi pemahaman konsep matematis yang diperolehnya.

Lain halnya, pada kelas yang dikenai model pembelajaran kooperatif tipe STAD. Hasil uji korelasi menyimpulkan bahwatidak terdapat korelasi positif antara gaya kognitif dengan pemahaman konsep matematis siswa. Hal ini menunjukkan bahwa pada model pembelajaran kooperatif tipe $S T A D$, kuat atau lemahnya gaya kognitif field dependent seorang siswa tidak berpengaruh terhadap pemahaman konsep matematis siswa.

Karena hasil penggolongan gaya kognitif siswa menunjukkan bahwa seluruh siswa memiliki gaya kognitif field dependent, maka hasil pengujian hipotesis sesuai dengan karakteristik siswa yang memiliki gaya kognitif field dependent.
Mencermati karakteristik siswa yang memiliki gaya kognitif field dependent yang cenderung lebih menyukai mata pelajaran sosial dibandingkan mata pelajaran matematika dan memiliki kesulitan yang besar untuk mempelajari konsepkonsep yang terstruktur, seperti matematika, sebagian besar siswa kurang bersemangat dalam mengikuti pelajaran matematika. Karena cenderung kurang memiliki ketertarikan terhadap mata pelajaran matematika, dalam pembelajarannya siswa lebih suka untuk dijelaskan dibandingkan diminta untuk mengerjakan lembar kerja. Dengan demikian, siswa yang memiliki gaya kognitif field dependent cenderung lebih nyaman dalam mengikuti model pembelajaran langsung dibandingkan model pembelajaran STAD.

Langkah pembelajaran yang cenderung berbeda sangat signifikan antara model pembelajaran langsung dan STAD memberikan pengaruh pada siswa yang memiliki gaya kognitif field dependent dalam memahami konsep yang sedang dipelajari. Menurut Desmita (2009: 149), karakter pembelajaran pada diri siswa yang memiliki gaya kognitif field dependent cenderung hanya mampu menerima konsep yang diberikan dan mengalami kesulitan untuk mengorganisasi kembali. Selain itu, siswa yang memiliki gaya kognitif field dependentcenderung memerlukan instruksi yang lebih jelas mengenai bagaimana 
memecahkan masalah. Karakteristikkarakteristik ini cenderung cocok jika dikenai model pembelajaran langsung. Dalam model pembelajaran langsung dengan metode ceramah dan atau ekspositori, siswa cenderung menerima penjelasan secara terstruktur. Lain halnya pada model pembelajaran $S T A D$, siswa cenderung dituntut untuk mengkonstruksi sendiri pemahamannya melalui kelompok. Model pembelajaran STAD yang menggunakan lembar kerja sebagai medianya tidak sesuai jika dikenai pada siswa gaya kognitif field dependent yang cenderung mengalami kesulitan dalam mengonstruksi sendiri pemahaman matematisnya.

\section{KESIMPULAN}

Berdasarkan hasil penelitian dan pembahasan, diperoleh kesimpulan bahwa pada (1) kelas yang dikenai model pembelajaran langsung, terdapat korelasi positif antara gaya kognitif dengan pemahaman konsep matematis siswa dan (2) kelas yang dikenai model pembelajaran $S T A D$, tidak terdapat korelasi positif antara gaya kognitif dengan pemahaman konsep matematis siswa.

\section{REFERENSI}

Budiyono. 2009. Statistika untuk Penelitian. Surakarta: Sebelas Maret University Press.

Desmita. 2009. Psikologi Perkembangan Peserta Didik. Bandung: PT. Remaja Rosdakarya.
Ernawati. 2003. Meningkatkan Kemampuan Pemahaman Konsep Matematika Siswa SMU Melalui Pembelajaran Berbasis Masalah. Skripsi. Bandung: Jurusan Pendidikan Matematika FPMIPA UPI.

Isjoni, H. 2010. Pembelajaran Kooperatif. Yogyakarta: Pustaka Pelajar.

Kepner, MD. dan Neimark, ED. 1984. "Test-retest Reliability and Differential Pattern of Score Change on the Group Embedded Figures Test" dalam Journal of Personality and Social Psychology. Vol. 46 (6). pp. 1405-1413.

Moertiningsih, $\quad$ E.P.U. 2011. Eksperimentasi Model Pembelajaran Kooperatif Tipe Jigsaw yang Dimodifikasi Ditinjau dari Gaya Kognitif Siswa Kelas VIII SMP Negeri di Kabupaten Grobogan Tahun 2010/2011. Tesis. Surakarta: Universitas Sebelas Maret.

Mulyasa, E. 2003. Kurikulum Berbasis Kompetensi. Bandung: Remaja Rosda Karya.

Nasution, S. 2008. Berbagai Pendekatan dalam Proses Belajar \& Mengajar. Jakarta: PT Bumi Aksara.

Purwanto, M.N. 1994. Prinsip-prinsip dan Teknik Evaluasi Pengajaran Pendidikan. Bandung: Remaja Rosdakarya

Ruseffendi, E.T. 2006. Pengantar kepada Membantu Guru Mengembangkan Kompetensinya dalam Pengajaran Matematika untuk Meningkatkan CBSA. Bandung: Tarsito.

Sanjaya, Wina. 2009. Strategi Pembelajaran Berorientasi Standar Proses Pendidikan. Jakarta: Kencana Prenada Media Group. 
Gaya Kognitif Field Dependent dan Tingkat Pemahaman Konsep Matematis Antara Pembelajaran Langsung dan STAD

Agung Putra Wijaya

Saputro, Mahardi. 2011. Analisis Kemampuan Pemecahan Masalah Matematika Berdasarkan LangkahLangkah Polya Ditinjau dari Gaya Kognitif Siswa. Tesis. Surakarta: Universitas Sebelas Maret.

Setiawan, Wawan. 2010. "Penerapan Model Pengajaran Langsung (Direct Instruction) untuk Meningkatkan Pemahaman Belajar Siswa dalam Pembelajaran Rekayasa Perangkat Lunak (RPL)" dalam Jurnal Pendidikan Teknologi Informasi dan Komunikasi (PTIK). Vol. 3 No. 1/Juni 2010 Hal. 7-10.

Shadiq, Fadjar. 2007. Inovasi Pembelajaran Matematika dalam Rangka Menyongsong Sertifikasi Guru dan Persaingan Global. Makalah disampaikan pada Seminar dan Lokakarya Pembelajaran Matematika. P4TK (PPPG) Matematika. 15-16 Maret 2007.
Slameto. 2003. Belajar dan Faktor-Faktor yang Mempengaruhinya. Jakarta: PT. Asdi Mahasatya.

Slavin, R.E. 2010. Cooperative Learning: Teori, Riset, dan Praktik. (Edisi terjemahan oleh Narulita Yusron). Bandung: Nusa Media.

Sudrajat, Akhmad. 2011. Model Pembelajaran Langsung (Direct Instruction). Diunduh di http://akhmadsudrajat.wordpress.com /2011/01/27/model-pembelajaranlangsung/. pada 01 Juni 2013.

Virlianti, Y. 2002. Analisis Pemahaman Konsep Siswa dalam Memecahkan Masalah kontekstual pada Pembelajaran Matematika Melalui Pendekatan Realistik. Skripsi. Bandung: Jurusan Pendidikan Matematika FMIPA UPI.

Uno, Hamzah B. 2006. Orientasi dalam Psikologi Pembelajaran. Jakarta: Bumi Aksara. 